\title{
Mitogenic Signaling by ATP/P2Y Purinergic Receptors in Astrocytes: Involvement of a Calcium-Independent Protein Kinase C, Extracellular Signal-Regulated Protein Kinase Pathway Distinct from the Phosphatidylinositol-Specific Phospholipase C/Calcium Pathway
}

\author{
Joseph T. Neary, Yuan Kang, Yurong Bu, Esther Yu, Katherine Akong, and Christopher M. Peters \\ Research Service, Veterans Affairs Medical Center, and Departments of Pathology and Biochemistry and Molecular \\ Biology, University of Miami School of Medicine, Miami, Florida 33125
}

Activation of ATP/P2Y purinergic receptors stimulates proliferation of astrocytes, but the mitogenic signaling pathway linked to these G-protein-coupled receptors is unknown. We have investigated the role of extracellular signal-regulated protein kinase (ERK) in $\mathrm{P} 2 \mathrm{Y}$ receptor-stimulated mitogenic signaling as well as the pathway that couples P2Y receptors to ERK. Downregulation of protein kinase $\mathrm{C}(\mathrm{PKC})$ in primary cultures of rat cerebral cortical astrocytes greatly reduced the ability of extracellular ATP to stimulate ERK. Because occupancy of P2Y receptors also leads to inositol phosphate formation, calcium mobilization, and PKC activation, we explored the possibility that signaling from $\mathrm{P} 2 \mathrm{Y}$ receptors to ERK is mediated by a phosphatidylinositol-specific phospholipase C (PI-PLC)/calcium pathway. However, neither inhibition of PI-PLC nor chelation of calcium significantly reduced ATP-stimulated ERK activity. Moreover, a preferential inhibitor of calcium-dependent PKC isoforms, Gö 6976, was significantly less effective in blocking ATP-stimulated ERK activity than GF102903X, an inhibitor of both calcium-dependent and -independent PKC isoforms. Furthermore, ATP stimulated a rapid translocation of $\mathrm{PKC} \delta$, a calcium-independent PKC isoform, but not PKC $\gamma$, a calcium-dependent PKC isoform. ATP also stimulated a rapid increase in choline, and inhibition of phosphatidylcholine hydrolysis blocked ATP-evoked ERK activation. These results indicate that $\mathrm{P} 2 \mathrm{Y}$ receptors in astrocytes are coupled independently to PI-PLC/calcium and ERK pathways and suggest that signaling from $\mathrm{P} 2 \mathrm{Y}$ receptors to ERK involves a calciumindependent PKC isoform and hydrolysis of phosphatidylcholine by phospholipase D. In addition, we found that inhibition of ERK activation blocked extracellular ATP-stimulated DNA synthesis, thereby indicating that the ERK pathway mediates mitogenic signaling by $\mathrm{P} 2 \mathrm{Y}$ receptors.

Key words: purinergic receptors; MAP kinase; protein kinase C; proliferation; phospholipases; astrocytes
Emerging evidence points to a crucial role for extracellular signal-regulated protein kinases (ERK1 and ERK2) in regulating cellular proliferation and differentiation (for review, see Marshall, 1995; Neary, 1997). ERKs are part of a family of serine/threonine protein kinases known as mitogen-activated protein kinases (MAPKs) (Seger and Krebs, 1995). These enzymes are components of a signaling cascade consisting of at least three cytoplasmic protein kinases that are activated sequentially. ERKs are activated by phosphorylation on tyrosine and threonine residues by a dual-specificity protein kinase termed MAPK/ERK kinase (MEK). MEK in turn is activated by phosphorylation on serine/ threonine residues, which can be catalyzed either by the Raf family of protein kinases, the protooncogene product Mos, or MEK kinases (Avruch et al., 1994). The ERK/MAPK cascade is stimulated shortly after extracellular signals bind to cell surface receptor tyrosine kinases or heterotrimeric G-protein-coupled receptors (GPCRs). These receptors are linked to the ERK/ MAPK cascade by a sequence of protein-protein interactions and by upstream protein kinases such as protein kinase C (PKC). The activated ERK can then translocate to the nucleus where it

\footnotetext{
Received Nov. 16, 1998; revised March 9, 1999; accepted March 15, 1999.

This work was supported by the Department of Veterans Affairs.

Correspondence should be addressed to Dr. J. T. Neary, Research Service 151, Veterans Affairs Medical Center, 1201 NW 16th Street, Miami, FL 33125.

Copyright (C) 1999 Society for Neuroscience $0270-6474 / 99 / 194211-10 \$ 05.00 / 0$
}

can activate or induce transcription factors such as Elk-1 and c-Fos (Karin, 1995). In this manner, ERKs provide a link between cytoplasmic and nuclear signaling, ultimately leading to changes in gene expression involved in proliferation and differentiation.

Recent studies on the role of extracellular ATP in the brain have demonstrated that in addition to serving as an excitatory neurotransmitter (Edwards et al., 1992; Harms et al., 1992; Shen and North, 1993), ATP can also exert mitogenic and morphogenic activity on glial and neuronal cells (Neary et al., 1996). For example, treatment of astrocytes with ATP leads to increases in DNA synthesis (Rathbone et al., 1992; Abbracchio et al., 1994; Neary et al., 1994b), in process formation (Neary et al., 1994b) and elongation (Abbracchio et al., 1994, 1995), and in the content of glial fibrillary acidic protein (Neary et al., 1994b), an astrocytespecific marker that is upregulated after brain injury (Eng, 1988). These trophic actions of ATP may be important in development and synaptogenesis as well as in tissue injury and repair, but the signaling mechanisms underlying the trophic activity of ATP are unknown.

The biological actions of extracellular ATP are mediated by cell surface receptors designated as $\mathrm{P} 2$ purinoceptors (Burnstock, 1978). This general class of receptors has been categorized into two major types: ligand-gated ionotropic receptors $(\mathrm{P} 2 \mathrm{X})$ and G-protein-coupled metabotropic receptors (P2Y) (Abbracchio 
and Burnstock, 1994). P2Y receptors are expressed in astrocytes, and these receptors are coupled to phosphatidylinositol-specific phospholipase C (PI-PLC), leading to inositol phosphate formation and calcium mobilization (Pearce et al., 1989; Neary et al., 1991; Kastritsis et al., 1992; Salter and Hicks, 1994, 1995; King et al., 1996; Centemeri et al., 1997). After activation of the PI-PLC/ calcium pathway, PKC is then activated.

We have shown that $\mathrm{P} 2 \mathrm{Y}$ receptors in astrocytes are also linked to the ERK/MAPK cascade (Neary and Zhu, 1994; King et al., 1996). However, the signaling elements that couple the P2Y receptors to the ERK/MAPK cascade have not been defined. Preliminary evidence indicates that signaling from $\mathrm{P} 2 \mathrm{Y}$ receptors to ERK in astrocytes is dependent on PKC (Neary, 1996). Because P2Y receptor signaling can involve PKC in both PI-PLC and ERK pathways, we have investigated the hypothesis that PI-PLC/calcium are upstream of ERK. We report here for the first time that P2Y receptors are coupled independently to PIPLC and ERK pathways and that the latter pathway involves hydrolysis of phosphatidylcholine (PC) and a calciumindependent isoform of PKC. We also provide evidence that the ERK pathway mediates ATP-induced mitogenic signaling in astrocytes.

\section{MATERIALS AND METHODS}

Cell culture and treatment. Primary astrocytes were obtained from neonatal rat (Fischer) cerebral cortices as described previously (Neary et al., 1994a). Cells were seeded at densities of 150,000 cells/well in 24-well plates (for DNA synthesis studies) or at 300,000 cells $/ 35 \mathrm{~mm}$ or 600,000 cells/60 mm plates (for ERK studies); cells were not replated before use. At least $99 \%$ of the cell population were astrocytes, as determined by staining with cell-specific markers (Neary et al., 1994a). Experiments were conducted with 3- to 6-week-old cultures. Before treatment with nucleotides or other agents, cells that had been maintained in DMEM containing $10 \%$ horse serum were shifted to the quiescent phase by incubation in DMEM containing $0.5 \%$ horse serum for $48-72 \mathrm{hr}$. Stock solutions of nucleotides and drugs were divided into single-use aliquots and stored at $-80^{\circ} \mathrm{C}$, except for D609 (Research Biochemicals International, Natick, MA), which was prepared fresh for each experiment.

$D N A$ synthesis. ${ }^{3} \mathrm{H}$-thymidine incorporation was measured as described previously (Neary et al., 1994a) using confluent cells in the stationary phase of growth. In brief, nucleotides or PD 098059 (Research Biochemicals International) or both at the indicated final concentrations were added to the media in the wells in triplicate or quadruplicate. PD 098059 was added $60 \mathrm{~min}$ before addition of nucleotides. As a positive control, some wells were treated with $10 \%$ horse serum, whereas untreated cultures were used for negative controls. After $18 \mathrm{hr},{ }^{3} \mathrm{H}$-thymidine $(0.5$ $\mu \mathrm{Ci} / \mathrm{ml}$ culture media; $83 \mathrm{Ci} / \mathrm{mmol}$; ICN Biochemicals, Costa Mesa, CA) was added to the media in the wells for an additional $4 \mathrm{hr}$. Cells were then rinsed with Dulbecco's PBS (D-PBS), incubated in 10\% trichloroacetic acid for 30 min on ice, rinsed again with D-PBS, and lysed in 1\% SDS, $0.3 \mathrm{~N} \mathrm{NaOH}$. Aliquots were neutralized and counted by liquid scintillation spectrometry.

ERK activity. After treatment with nucleotides or other agents for the times and concentrations indicated, cells were rinsed quickly in ice-cold D-PBS and lysed in a buffer containing $20 \mathrm{~mm}$ Tris, $\mathrm{pH} 7.0,0.27 \mathrm{M}$ sucrose, $1 \mathrm{~mm}$ EDTA, $1 \mathrm{~mm}$ EGTA, $50 \mathrm{~mm} \mathrm{NaF}, 1 \mathrm{~mm}$ dithiothreitol (DTT), $1 \mathrm{~mm}$ sodium orthovanadate, $10 \mathrm{~mm} \beta$-glycerophosphate, $5 \mathrm{~mm}$ sodium pyrophosphate, and $1 \%$ Triton X-100. In some cases, cells were lysed in a buffer containing $20 \mathrm{~mm}$ Tris, pH 7.5, $100 \mathrm{~mm} \mathrm{NaCl,} 50 \mathrm{~mm}$ NaF, 2 mM EGTA, 50 mM $\beta$-glycerophosphate, 1 mm sodium orthovanadate, $100 \mu \mathrm{g} / \mathrm{ml}$ 4-(2-aminoethyl) benzenesulfonylfluoride (AEBSF; Calbiochem, La Jolla, CA), $0.3 \mathrm{U} / \mathrm{ml}$ aprotinin, and $1 \%$ Triton $\mathrm{X}-100$. The lysates were centrifuged in a microfuge for $5 \mathrm{~min}$ at $4^{\circ} \mathrm{C}$. ERK activity was measured as described previously (Neary and Zhu, 1994). In brief, aliquots (20 $\mu \mathrm{l}$ containing $10-20 \mu \mathrm{g}$ protein) of the supernatants were assayed at $30^{\circ} \mathrm{C}$ for $20 \mathrm{~min}$ in a final reaction solution containing $10 \mu \mathrm{M}$ $\operatorname{ATP}\left(0.2 \mu \mathrm{Ci}\left[\gamma^{32} \mathrm{P}\right] \mathrm{ATP} ; 3000 \mathrm{Ci} / \mathrm{mmol}\right.$; New England Nuclear $), 10 \mathrm{~mm}$ $\mathrm{MgCl}_{2}, 1 \mu \mathrm{M}$ okadaic acid, and $0.33 \mathrm{mg} / \mathrm{ml}$ bovine brain myelin basic protein (MBP) in a final volume of $40 \mu \mathrm{l}$. Under these conditions, the reaction is linear with respect to time and enzyme concentration. Reac- tions were stopped by pipetting $20 \mu \mathrm{l}$ aliquots onto $1 \times 2 \mathrm{~cm}$ strips of phosphocellulose paper (Sevetson et al., 1993) and immediately placing the strips in $75 \mathrm{~mm}$ phosphoric acid. Strips were washed for a minimum of $2 \mathrm{hr}$ and rinsed three times for $5 \mathrm{~min}$ each in $75 \mathrm{~mm}$ phosphoric acid and once in ethanol. Strips were dried and transferred to scintillation vials, and radioactivity was assessed by liquid scintillation counting. ERK activity was expressed as picomoles of ${ }^{32} \mathrm{P}$ transferred per minute per milligram of protein. Protein concentrations were determined by the modified Lowry procedure as described (Peterson, 1983), with bovine serum albumin as standard. The validity of the phosphocellulose strip assay under these conditions was confirmed by comparing the data with phosphorylation of MBP obtained by SDS-PAGE of the samples followed by autoradiography and densitometry (Bio-Rad GS-670 imaging densitometer; Bio-Rad, Hercules, CA); a correlation coefficient of 0.935 was obtained (Neary and Zhu, 1994). Results obtained by this procedure were consistent with those obtained by immunocomplex kinase assays after immunoprecipitation with anti-ERK1/2 (Santa Cruz Biotechnology, Santa Cruz, CA) as described previously (Neary and Zhu, 1994) or by determination of phosphorylated ERK1/2 as described below.

Anion exchange chromatography. The procedure of Ahn et al. (1990) was used with some modifications. After treatment of cultures with ATP (six $60 \mathrm{~mm}$ plates per group), plates were rinsed quickly in ice-cold PBS. Cells were scraped and homogenized in buffer A $(50 \mathrm{~mm}$ $\beta$-glycerophosphate, $\mathrm{pH} 7.3,0.1 \mathrm{~mm}$ sodium orthovanadate, $1.5 \mathrm{~mm}$ EGTA, $1 \mathrm{~mm}$ DTT), and the homogenate was centrifuged at $13,000 \times g$ for $10 \mathrm{~min}$ at $4^{\circ} \mathrm{C}$. Supernatants were stored at $-70^{\circ} \mathrm{C}$. Before chromatography, supernatants were thawed and centrifuged for $30 \mathrm{~min}$ at $23,000 \times g, 4^{\circ} \mathrm{C}$. Supernatants containing equivalent amounts of protein were loaded onto a $1 \mathrm{ml} \mathrm{Hi-Trap} \mathrm{Q} \mathrm{(Amersham} \mathrm{Pharmacia} \mathrm{Biotech)}$ column at a flow rate of $0.5 \mathrm{ml} / \mathrm{min}$. Fractions $(1 \mathrm{ml})$ were collected with a Gradifrac protein purification system (Amersham Pharmacia Biotech), and the column was washed with $8 \mathrm{ml}$ buffer A. Elution was conducted with a $60 \mathrm{ml}$, linear $\mathrm{NaCl}$ gradient $(0-400 \mathrm{~mm} \mathrm{NaCl}$ in buffer $\mathrm{A})$. Fractions $(20 \mu \mathrm{l})$ were assayed for ERK activity as described above using MBP as substrate. In addition, ERK1/2 was detected in column fractions and cellular extracts by immunoblotting as described below.

Membrane preparation. After quiescent cultures were treated with ATP or 12-O-tetradecanoylphorbol-13-acetate (TPA) for the time periods indicated in the text, cells were quickly rinsed twice with ice-cold PBS and collected in $200 \mu \mathrm{l}$ (per $35 \mathrm{~mm}$ plate; four plates/group) of a buffer containing $50 \mathrm{~mm}$ Tris, pH 7.7, 2 mM EGTA, $5 \mathrm{~mm}$ DTT, $100 \mu \mathrm{g} / \mathrm{ml}$ AEBSF, and $10 \mu \mathrm{g} / \mathrm{ml}$ leupeptin. Cells were homogenized (20 strokes) using a Teflon-glass homogenizer, and homogenates were centrifuged at $100,00 \times g$ for $60 \mathrm{~min}, 4^{\circ} \mathrm{C}$, in a Beckman TL-100 centrif uge. Pellets were suspended in $800 \mu \mathrm{l}$ of the homogenizing buffer containing $1 \%$ Triton $\mathrm{X}-100$. Suspensions were incubated on ice for $30 \mathrm{~min}$ and sonicated for 5-10 sec (Ultrasonic 40W, Heat Systems, Farmingdale, NY). Protein concentrations were determined by the modified Lowry procedure (Peterson, 1983). Fractions were diluted in $2 \times$ Laemmli SDS sample buffer (Laemmli, 1970) and heated in a boiling water bath for $5 \mathrm{~min}$.

Immunoblotting. Samples containing equal amounts of protein were subjected to SDS-PAGE (Laemmli, 1970) using 11\% acrylamide and transferred to nitrocellulose filters with a Genie electrophoretic blotter (Idea Scientific, Minneapolis, MN) for $1 \mathrm{hr}$ at $12 \mathrm{~V}$ in a transfer buffer containing $25 \mathrm{~mm}$ Tris, $192 \mathrm{~mm}$ glycine, and 20\% methanol. Filters were incubated with a blocking solution containing $20 \mathrm{~mm}$ Tris, $\mathrm{pH}$ 7.7, 137 $\mathrm{mm} \mathrm{NaCl}, 0.1 \%$ Tween 20 (TTBS), and 5\% nonfat dry milk for $1 \mathrm{hr}$ at room temperature, rinsed in TTBS, and then incubated for $1 \mathrm{hr}$ at room temperature with specific antibodies diluted in TTBS [anti-phosphoERK1/2 (1/20,000; Promega, Madison, WI), anti-ERK1/2 (1/500; Santa Cruz Biotechnology), anti-PKC $\delta(1 / 200$; Transduction Laboratories, Lexington, KY), or anti-PKC $\gamma(1 / 5000$; Transduction Laboratories)]. After three rinses in TTBS, filters were incubated for $1 \mathrm{hr}$ at room temperature with peroxidase-conjugated anti-rabbit or anti-mouse IgG diluted in TTBS (1/20,000 or 1/10,000, respectively; Amersham Life Sciences, Arlington Heights, IL). Filters were washed three times in TTBS, and proteins were detected by enhanced chemiluminescence (Amersham Life Sciences).

Inositol phosphate formation. Inositol phosphates were measured by a previously described procedure that involves prelabeling cells overnight with myo-[2- $\left.{ }^{3} \mathrm{H}(\mathrm{N})\right]$ inositol $(12.3 \mathrm{Ci} / \mathrm{mmol}$; New England Nuclear), stimulating with ATP as described in the text, applying aqueous extracts to Dowex AG 1-X8 columns, and eluting inositol phosphates with $1 \mathrm{M}$ ammonium formate/0.1 M formic acid (Bender et al., 1993). The ${ }^{3} \mathrm{H}$ 


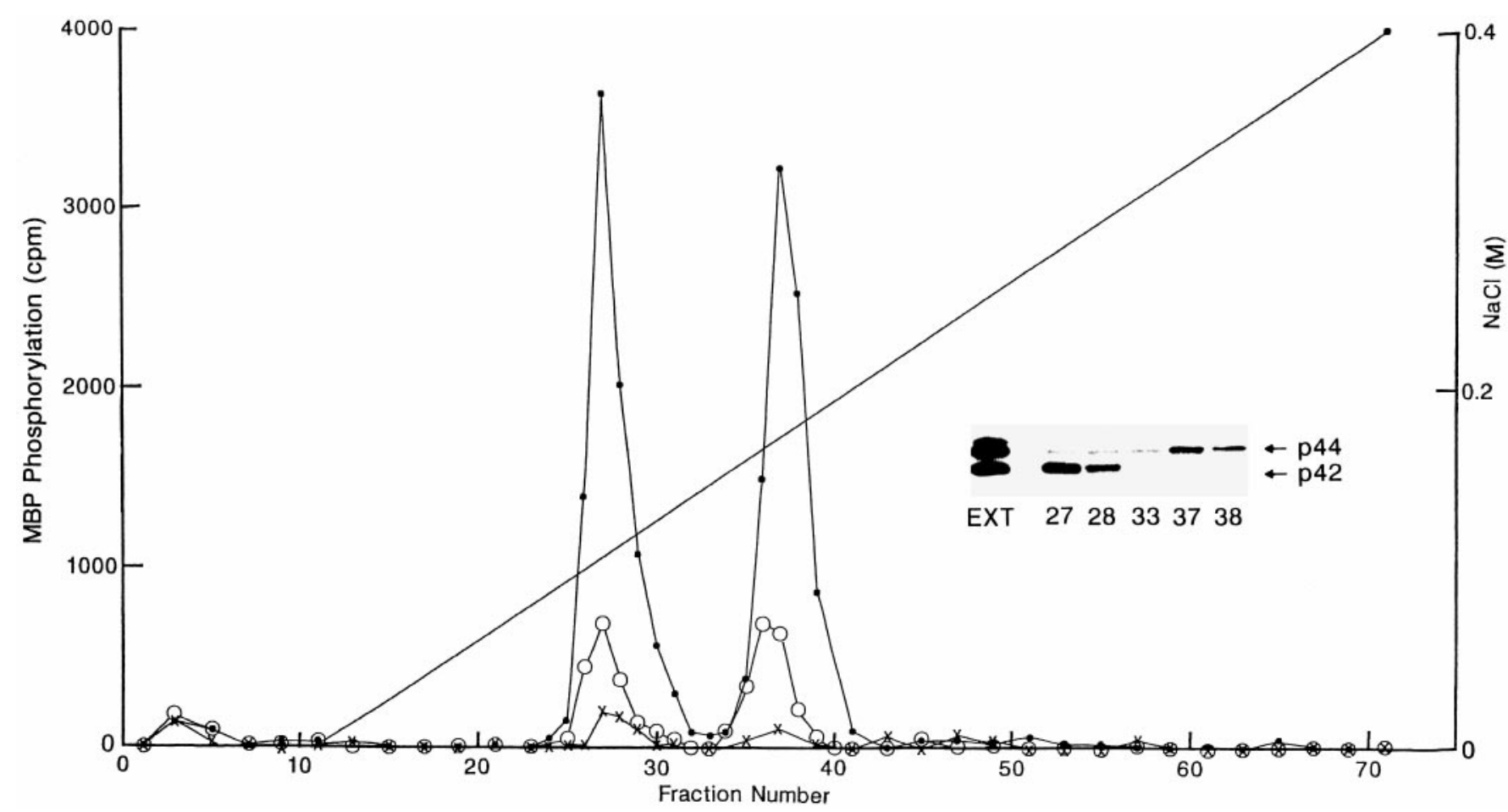

Figure 1. Signaling from P2Y receptors to ERK is dependent on PKC. Primary rat astrocyte cultures were treated with $100 \mu \mathrm{M}$ ATP for 15 min $(\bullet-\bullet)$, with $100 \mathrm{nM}$ TPA for $24 \mathrm{hr}$ before application of $100 \mu \mathrm{M}$ ATP for $15 \mathrm{~min}(\bigcirc-\bigcirc)$, or were untreated $(\times-\times)$. Homogenates were centrifuged, and supernatants containing equivalent amounts of protein were applied to a $1 \mathrm{ml} \mathrm{Hi-Trap} \mathrm{Q} \mathrm{anion} \mathrm{exchange} \mathrm{column} \mathrm{as} \mathrm{described} \mathrm{in} \mathrm{Materials} \mathrm{and} \mathrm{Methods.}$ Fractions $(1 \mathrm{ml})$ were collected at a flow rate of $0.5 \mathrm{ml} / \mathrm{min}$, and proteins were eluted with a linear, $60 \mathrm{ml} \mathrm{NaCl}$ gradient $(0-400 \mathrm{mM})$. Two peaks of ERK activity eluted at 110 and $175 \mathrm{~mm} \mathrm{NaCl}$. Inset, Immunoblot of column fractions from the peak ERK regions and a fraction between the peaks. The indicated column fractions and the cellular extract $(E X T)$ from the ATP-treated, normal cells were subjected to SDS-PAGE, and immunoblots were probed with anti-ERK1/2. The arrows indicate the two ERK isoforms p42 and p44, before and after fractionation by anion exchange chromatography. Similar results were obtained by chromatography on a $1 \mathrm{ml}$ Resource Q (Amersham Pharmacia Biotech) column.

recovered in inositol phosphates was then standardized to an incorporation of $10^{5} \mathrm{cpm}$ in the lipid fraction.

$P C$ hydrolysis. Cells were incubated with ${ }^{3} \mathrm{H}$-choline, and water-soluble ${ }^{3} \mathrm{H}$-choline-labeled metabolites were separated and quantitated as described (Vance et al., 1980) with some modifications. In brief, cultures grown on $35 \mathrm{~mm}$ dishes were incubated in DMEM/0.5\% horse serum containing $2.5 \mu \mathrm{Ci}\left[\mathrm{methyl}{ }^{3} \mathrm{H}\right]$-choline $(\mathrm{NEN} ; 60-90 \mathrm{Ci} / \mathrm{mmol}) / \mathrm{ml}$ for $48 \mathrm{hr}$ followed by a $24 \mathrm{hr}$ incubation in DMEM/0.5\% horse serum. After treatment with ATP for the times indicated, the media was quickly removed, and $2.1 \mathrm{ml}$ of extraction solution (methanol/10 mM glycine, $\mathrm{pH}$ $3.0 ; 5: 2, \mathrm{v} / \mathrm{v}$ ) was added immediately. Dishes were scraped, and the extract was transferred to $15 \mathrm{ml}$ centrifuge tubes. Chloroform $(0.8 \mathrm{ml})$ was added, tubes were vortexed, $0.8 \mathrm{ml}$ water and $0.8 \mathrm{ml}$ chloroform were added, tubes were vortexed again, and phases were separated by centrifugation at $660 \times g$ for $5 \mathrm{~min}$. The lipid phase was removed, and the aqueous phase was re-extracted with $0.8 \mathrm{ml}$ chloroform, followed by vortexing and centrifugation as described above. Aqueous phases were combined, and carrier choline, phosphocholine, cytidine 5'-diphosphocholine, and glycerophosphocholine $(50 \mu \mathrm{g}$ each) were added to a $0.5 \mathrm{ml}$ aliquot that was concentrated to $25 \mu \mathrm{l}$ by vacuum centrifugation. Samples were applied to a silica gel thin layer plate that was developed in $0.5 \%$ $\mathrm{NaCl}$, ethanol, methanol, $\mathrm{NH}_{4} \mathrm{OH}(5: 3: 2: 0.5 ; \mathrm{v} / \mathrm{v})$. The plate was dried at room temperature, and spots were detected by iodine vapor, scraped into scintillation vials containing $0.75 \mathrm{ml} 0.1 \mathrm{~N} \mathrm{NaOH}$, and incubated overnight at room temperature. Acetic acid $(75 \mu \mathrm{l}$ of $1.5 \mathrm{~N})$ was added to each vial, and radioactivity was determined by scintillation spectrometry. The ${ }^{3} \mathrm{H}$ recovered in the choline-containing fractions was then standardized to an incorporation of $10^{5} \mathrm{cpm}$ in the aqueous phase.

Statistical analyses. All experiments were conducted a minimum of three times, each time with cultures from different seedings. Data were analyzed by Student's $t$ tests for two groups or ANOVA followed by post hoc comparisons for multiple groups with an Instat software package (GraphPad Software).

\section{RESULTS}

\section{Signaling from ATP/P2Y receptors to ERK in astrocytes is dependent on PKC}

P2Y receptors are members of the heterotrimeric GPCR superfamily (Abbracchio and Burnstock, 1994). Signaling from GPCRs to the ERK/MAPK cascade can proceed by several distinct pathways, some of which involve PKC (van Biesen et al., 1996b; Neary, 1997). To determine whether signaling from astrocytic $\mathrm{P} 2 \mathrm{Y}$ receptors to ERK is dependent on PKC, primary cultures of rat cortical astrocytes were treated overnight with phorbol ester (TPA; $100 \mathrm{~nm}$ ) to downregulate PKC; such chronic treatment with TPA reduces PKC activity in astrocytes by at least $90 \%$ (Neary et al., 1988). After addition of extracellular ATP, cellular homogenates were then prepared and fractionated by anion exchange chromatography under conditions that separate $\mathrm{p} 42$ and p44 isoforms of ERK (Ahn et al., 1990). After stimulation of astrocytes with ATP (100 $\mu \mathrm{M}, 15 \mathrm{~min})$, two peaks of ERK activity were eluted at $\sim 110$ and $175 \mathrm{~mm} \mathrm{NaCl}$ (Fig. 1). Downregulation of PKC by chronic phorbol ester treatment reduced the ability of extracellular ATP to stimulate the two regions of ERK activity by $\sim 85 \%$ (Fig. 1). To confirm the presence of ERK in these two regions of activity, immunoblots of peak fractions and of a fraction between the peaks were probed with an antibody that recognizes both ERK1 and ERK2. As shown in the inset of Figure 1, the first peak contained ERK2 and the second peak contained ERK1. In separate experiments, astrocytes were treated acutely with phorbol ester (100 nM, 5 min); ERK activity was stimulated 
A

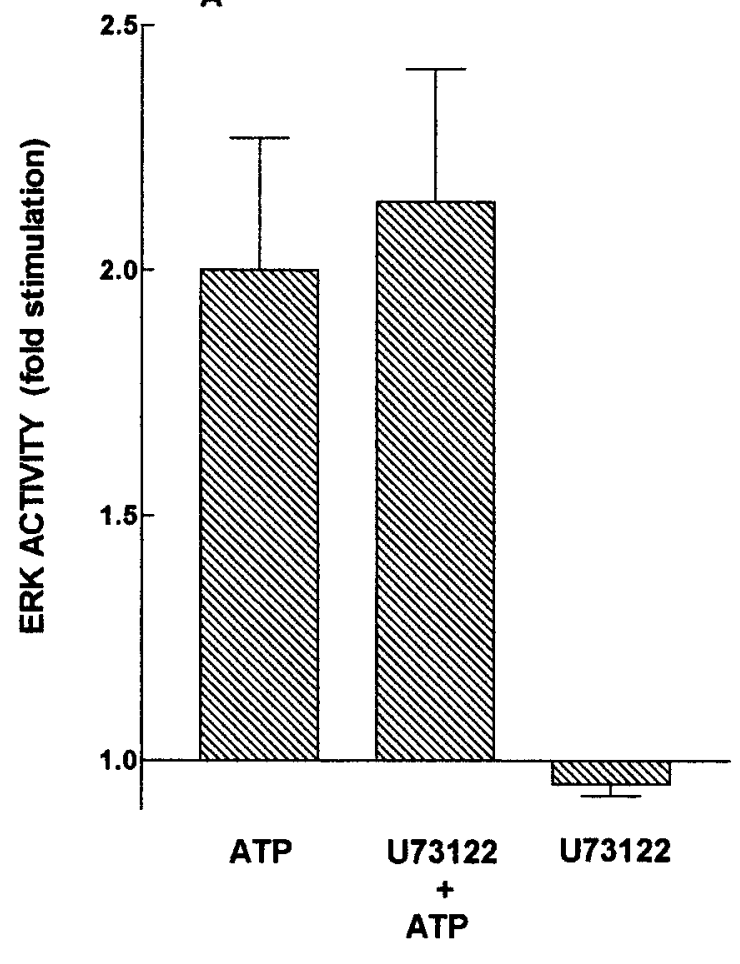

B

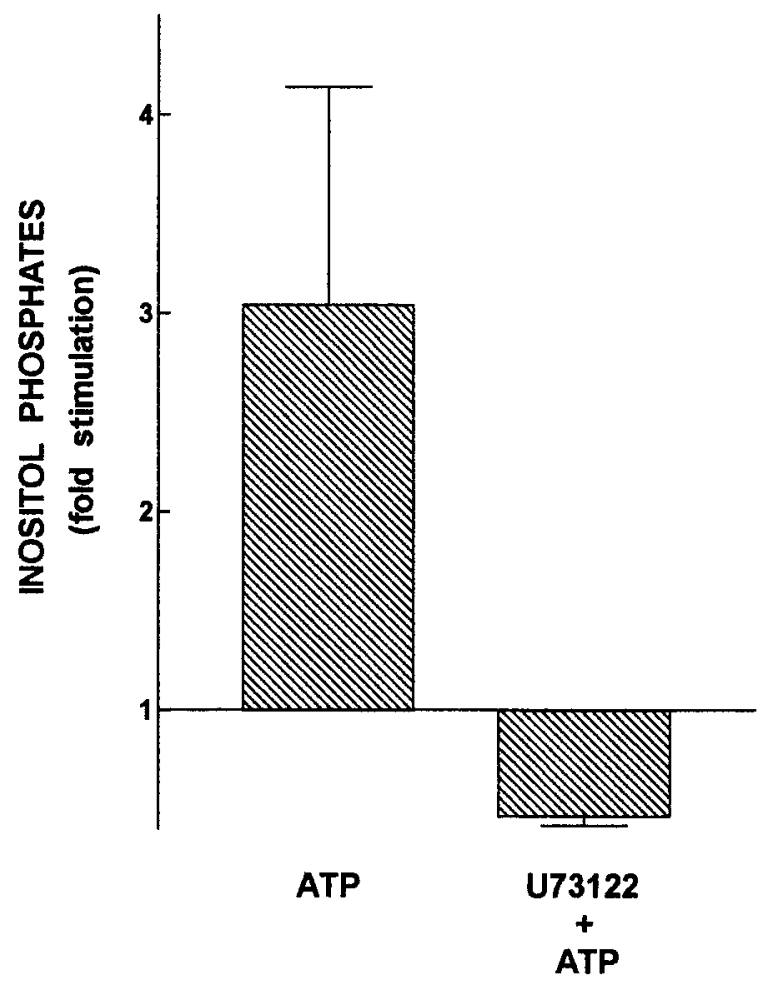

Figure 2. Inhibition of PI-specific PLC does not block ATP-stimulated ERK activity. In $A$, primary rat astrocyte cultures were treated with $10 \mu \mathrm{M}$ U73122 for $30 \mathrm{~min}$ before addition of ATP $(100 \mu \mathrm{M}, 15 \mathrm{~min})$. ERK activity data (mean \pm SEM) were obtained from three experiments, each conducted with duplicate culture plates. ERK activity in untreated cultures was $43.5 \pm 8.2$ pmol phosphate transferred per minute per milligram of protein. In $B$, primary rat astrocyte cultures were treated with $10 \mu \mathrm{M}$ U73122 for $30 \mathrm{~min}$ before addition of ATP (500 $\mu \mathrm{M}, 30 \mathrm{~min})$, and inositol phosphates were extracted and measured as described in Materials and Methods.

$2.95 \pm 0.13$-fold, thereby indicating that PKC can activate ERK in astrocytes.

\section{Inhibition of PI-PLC or chelation of calcium does not block ATP-stimulated ERK activation}

In astrocytes as in other cells, activation of P2Y receptors leads to mobilization of intracellular calcium via the PI-PLC pathway; the increased calcium, together with the PI-PLC-catalyzed increase in diacylglycerol, can then activate PKC. The finding that signaling from $\mathrm{P} 2 \mathrm{Y}$ receptors to ERK is dependent on $\mathrm{PKC}$ raised the possibility that PI-PLC, calcium, PKC, and ERK are part of the same signal transduction pathway. To determine whether PI-PLC and calcium are upstream of ERK, several approaches were used. To block signaling from P2Y receptors to ERK via PI-PLC, we used an inhibitor of PI-PLC, the steroidalamine U73122 (Bleasdale et al., 1990; Salter and Hicks, 1995). Cultures were treated with U73122 $(10 \mu \mathrm{M})$ for $30 \mathrm{~min}$ before application of extracellular ATP, after which ERK activity and inositol phosphate formation were measured. As shown in Figure 2A, U73122 did not diminish the ability of ATP to activate ERK. However, U73122 was effective in blocking ATP-evoked inositol phosphate formation (Fig. 2B). These findings suggest that activation of ERK by stimulation of $\mathrm{P} 2 \mathrm{Y}$ receptors can proceed independently of the PI-PLC pathway.

The ability of extracellular ATP to stimulate ERK independently of PI-PLC suggests that calcium mobilization is not required for activation of ERK by $\mathrm{P} 2 \mathrm{Y}$ receptors. To test this, we used BAPTA-AM to chelate intracellular calcium. Treatment of cells with $30 \mu \mathrm{M}$ BAPTA-AM for $30 \mathrm{~min}$ before application of ATP did not significantly reduce ERK activation (fold-stimulation: ATP, $2.64 \pm 0.05$; BAPTA + ATP, $2.68 \pm 0.12 ; p>0.05)$. As another approach, EGTA was used to minimize entry of extracellular calcium across the plasma membrane, an event that can occur in response to depletion of intracellular stores after application of ATP. However, treatment with 3 mM EGTA for 5 min, a condition known to block carbachol- and bradykininevoked activation of ERK (Lev et al., 1995), did not significantly reduce ATP-stimulated ERK activity (fold-stimulation: ATP, $2.57 \pm 0.25$; EGTA + ATP, $2.47 \pm 0.20 ; p>0.05)$.

\section{A calcium-independent PKC isoform mediates signaling from $\mathrm{P} 2 \mathrm{Y}$ receptors to ERK}

Because P2Y receptor signaling to ERK is independent of PIPLC and calcium, but dependent on PKC, we reasoned that a calcium-independent isoform of PKC may be involved in the $\mathrm{P} 2 \mathrm{Y} / \mathrm{ERK}$ pathway. If this is the case, a preferential inhibitor of calcium-dependent PKCs, Gö 6976 (Martiny-Baron et al., 1993), should have less of an effect on the stimulation of ERK by agonists of P2Y receptors than GF102903X, an inhibitor of both calcium-dependent and independent PKCs. To test this, cultures were treated with varying concentrations $(1,2.5$, or $5 \mu \mathrm{M})$ of Gö 6976 or GF102903X for 20 min before addition of ATP $(100 \mu \mathrm{M}$; 5 min). As shown in Figure 3A, Gö 6976 was less effective than GF102903X in inhibiting ATP stimulation of ERK activity. The greater degree of inhibition observed with GF109203X was significantly different from that observed with Gö 6976 for each of 

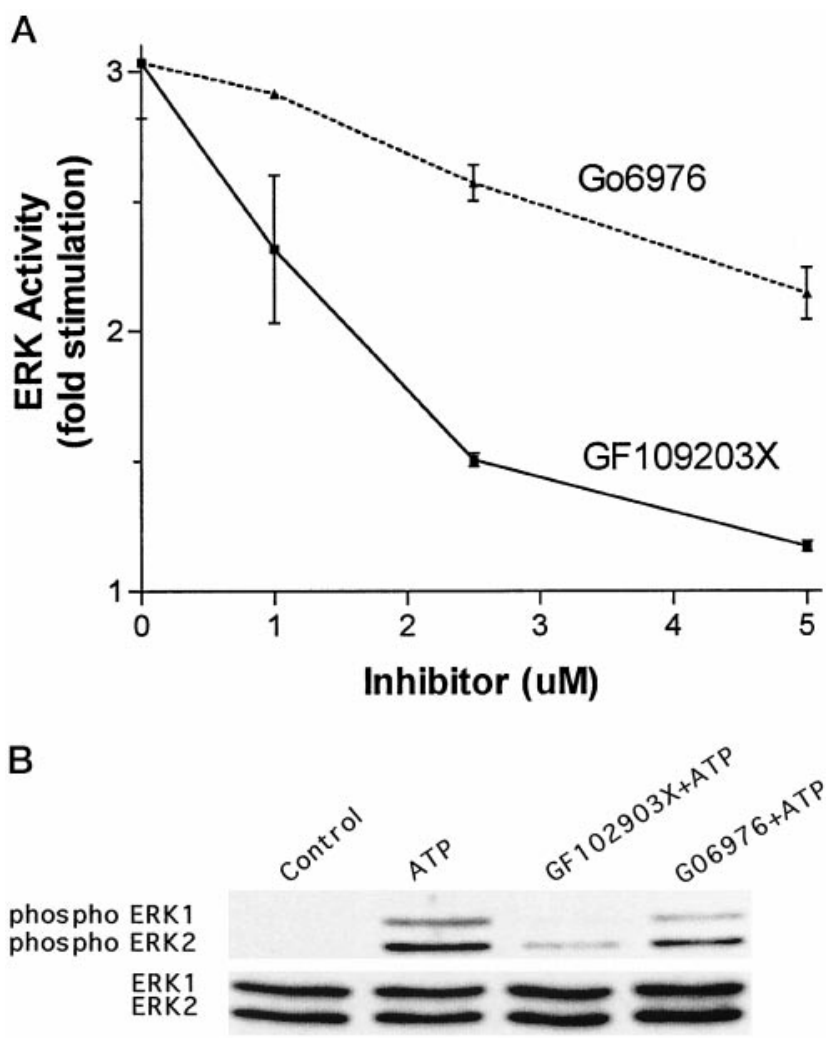

Figure 3. Effects of inhibitors of calcium-independent and -dependent $\mathrm{PKC}$ isoforms on signaling from $\mathrm{P} 2 \mathrm{Y}$ receptors to ERK. In $A$, primary rat astrocyte cultures were treated with ATP $(100 \mu \mathrm{M}, 5 \mathrm{~min})$ or with Gö 6976 (1-5 $\mu \mathrm{M}, 20 \mathrm{~min}$ ), which preferentially inhibits calcium-dependent PKC isoforms, or GF109203X (1-5 $\mu \mathrm{M}, 20 \mathrm{~min})$, an inhibitor of both calciumdependent and -independent PKC isoforms, before addition of ATP (100 $\mu \mathrm{M}, 5 \mathrm{~min}$ ). ERK activity data were obtained from a minimum of three experiments, each conducted with duplicate culture plates. In $B$, primary rat astrocyte cultures were treated with ATP $(100 \mu \mathrm{M}, 5 \mathrm{~min})$ or with Gö $6976(2.5 \mu \mathrm{M})$ or GF109203X $(2.5 \mu \mathrm{M})$ for $20 \mathrm{~min}$ before addition of ATP (100 $\mu \mathrm{M}, 5 \mathrm{~min}$ ), cells were lysed, and lysates containing equivalent amounts of protein were subjected to SDS-PAGE. Immunoblots were probed with antibodies that recognize phosphorylated ERK1/ERK2 (top panel) or ERK1/ERK2 (bottom panel).

the concentrations used $(p<0.01)$. To confirm this observation, we tested the effect of these inhibitors on ATP-evoked ERK phosphorylation, which was measured by immunoblot analysis with an antibody that recognizes dually phosphorylated ERK1 and ERK2 (Thr ${ }^{183}$, Tyr $^{185}$ ). As shown in Figure 3B, phosphorylation of ERK1 and ERK2 was only slightly reduced by Gö 6976, whereas GF102903X almost completely blocked ATP-evoked phosphorylation. These experiments support the concept that P2Y receptors are coupled to ERK by a calcium-independent isoform of PKC.

To determine whether activation of $\mathrm{P} 2 \mathrm{Y}$ receptors leads to translocation of a calcium-independent PKC isoform, membrane fractions from untreated and ATP-treated astrocytes were immunoblotted and probed with antibodies raised against $\mathrm{PKC} \delta$, a calcium-independent PKC isoform present in astrocytes (Gott et al., 1994). For comparison, translocation of $\mathrm{PKC} \gamma$, a calciumdependent $\mathrm{PKC}$ isoform, was also examined. As shown in Figure $4 A$, ATP stimulated a rapid translocation $(15 \mathrm{sec})$ of $\mathrm{PKC} \delta$, but not PKC $\gamma$. By contrast, PKC $\gamma$ was translocated by a phorbol ester TPA (100 nM, $5 \mathrm{~min}$ ) (Fig. $4 A$ ). Time course studies revealed that ATP-evoked translocation of $\mathrm{PKC} \delta$ was observed at $5 \mathrm{sec}$,
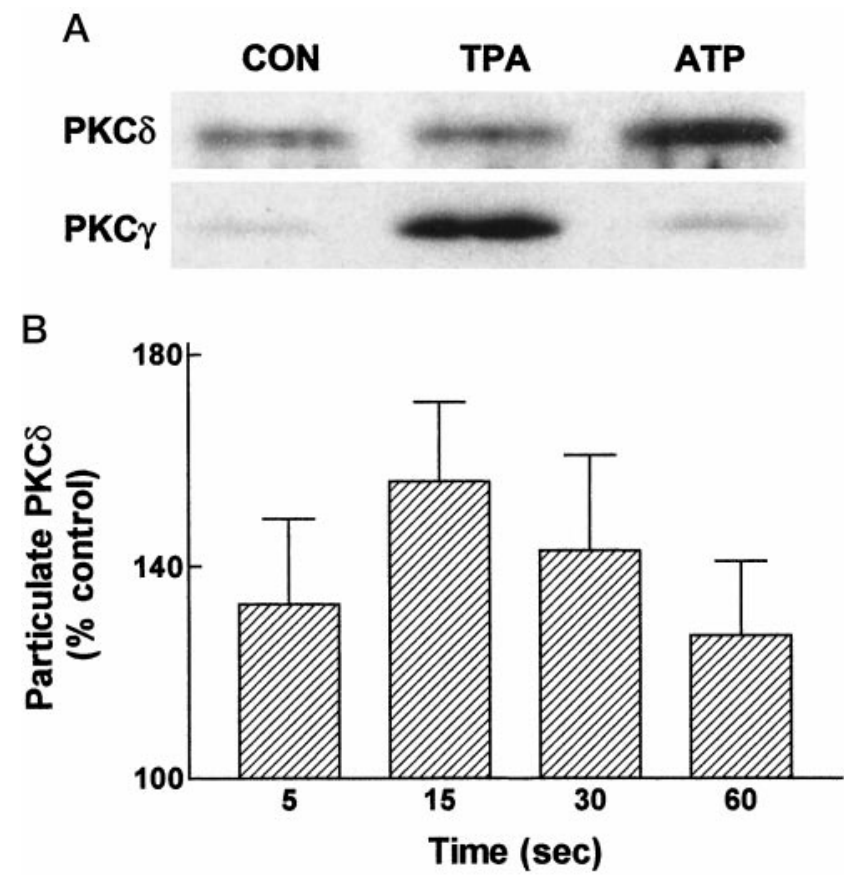

Figure 4. Extracellular ATP stimulates translocation of a calciumindependent $\mathrm{PKC}$ isoform. In $A$, primary rat astrocyte cultures were treated with or without $(C O N) 100 \mu \mathrm{M}$ ATP for $15 \mathrm{sec}$, or with $100 \mathrm{nM}$ TPA for $5 \mathrm{~min}$, and particulate fractions were prepared as described in Materials and Methods. Equal amounts of protein $(3.9 \mu \mathrm{g})$ were subjected to SDS-PAGE and analyzed by immunoblotting with monoclonal antibodies raised against PKC $\delta$ or PKC $\gamma$. In $B$, astrocytes were treated with $100 \mu \mathrm{M}$ ATP for the times indicated, and particulate fractions were obtained. Equal amounts of protein within each experiment (ranging from 4 to $5 \mu \mathrm{g}$ ) were analyzed by immunoblotting with a monoclonal antibody raised against $\mathrm{PKC} \delta$. Values given are mean \pm SEM; densitometric analysis (Bio-Rad GS-670) was conducted on a minimum of four to six independent experiments, each representing different culture seedings.

reached a peak at $15 \mathrm{sec}$, and declined from 30 to $60 \mathrm{sec}$ (Fig. $4 B$ ). This rapid translocation of PKC $\delta$ can be compared with time course studies of ERK activation, which showed that ATPstimulated ERK activity was detected at $1.5 \mathrm{~min}$ (Neary and Zhu, 1994), thereby indicating that PKC $\delta$ translocation occurs before ERK activation.

\section{Signaling from P2Y receptors to ERK is dependent on hydrolysis of phosphatidylcholine}

If $\mathrm{P} 2 \mathrm{Y}$ receptors signal to ERK by a pathway that involves a calcium-independent PKC and is independent of PI hydrolysis, we reasoned that the diacylglycerol needed to activate PKC may come from the hydrolysis of PC. To test this, time course studies were conducted to examine the ability of ATP to stimulate PC hydrolysis. We found that treatment of cultures with ATP led to the production of choline, which was observed at $15 \mathrm{sec}$ and peaked at 30 to $60 \mathrm{sec}$ (Fig. 5). This finding, together with a lack of increase in phosphocholine (data not shown), suggests that astrocytic P2Y receptors are coupled to phospholipase D (PLD) rather than PC-specific PLC. The time course of choline formation is consistent with the rapid translocation of $\mathrm{PKC} \delta$ and subsequent activation of ERK.

To determine whether PC hydrolysis is upstream of ERK activation, we used tricyclodecan-9-yl-xanthogenate (D609), which inhibits the hydrolysis of PC but not PI (Muller-Decker, 1989; Schutze et al., 1992; Cai et al., 1993; Inui et al., 1994; Kiss 


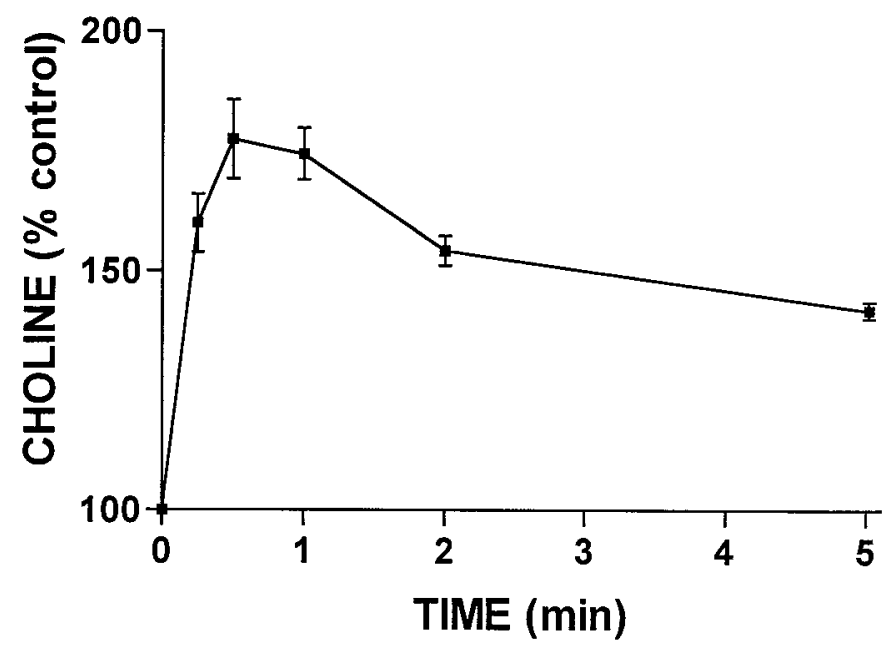

Figure 5. Extracellular ATP rapidly stimulates choline formation. Primary rat astrocyte cultures were incubated with ${ }^{3} \mathrm{H}$-choline $(2.5 \mu \mathrm{Ci} / \mathrm{ml})$ for $48 \mathrm{hr}$ followed by $24 \mathrm{hr}$ in choline-free culture medium before treatment with ATP $(100 \mu \mathrm{M})$ for the indicated times. Choline formation was measured as described in Materials and Methods. Similar results were obtained in two additional experiments.

and Tomono, 1995; van Dijk et al., 1997). Cultures were treated with D609 for $60 \mathrm{~min}$ before stimulation by ATP (100 $\mu \mathrm{M}, 5 \mathrm{~min})$. We found that D609 inhibited ATP-stimulated phosphorylation of ERK1 and ERK2 (Fig. 6A) and ERK activity (Fig. 6B) in a dose-dependent manner. At $50 \mu \mathrm{g} / \mathrm{ml}$ D609, a concentration frequently used to inhibit PC hydrolysis and diacyglycerol formation in intact cells (Muller-Decker, 1989; Schutze et al., 1992; Inui et al., 1994; Kiss and Tomono, 1995), ATP-stimulated ERK activity was reduced by $\sim 75 \%$, thereby indicating that signaling from P2Y receptors to ERK involves PC hydrolysis.

\section{Signaling from $\mathrm{P} 2 \mathrm{Y}$ receptors to ERK via pertussis toxin-sensitive and -insensitive G-proteins}

The type(s) of G-proteins involved in the P2Y/ERK pathway was studied by using pertussis toxin; this agent inactivates $\alpha$ subunits of the $G_{i}$ and $G_{o}$ families but does not affect $G_{s}$ or $G_{q}$ subunits (Yahame and Fung, 1993). Cultures were treated with $100 \mathrm{ng} / \mathrm{ml}$ pertussis toxin overnight (18-20 hr) before addition of ATP (100 $\mu \mathrm{M})$ for $5 \mathrm{~min}$. We found that pertussis toxin diminished the ability of ATP to stimulate ERK activity by $68 \pm 3 \%$ (mean \pm SEM; $p<0.0001 ; n=8$ ). These results suggest that coupling of $\mathrm{P} 2 \mathrm{Y}$ receptors in astrocytes to the ERK/MAPK cascade is mainly via pertussis toxin-sensitive G-proteins.

\section{Role of the ERK/MAPK cascade in mediating mitogenic signaling by $\mathrm{P} 2 \mathrm{Y}$ receptors}

To determine whether the ERK/MAPK cascade is involved in extracellular ATP-induced mitogenesis, we used PD 098059 [2-(2'amino-3' methoxypheny)-oxanaphthalen-4-one], a selective inhibitor of MEK1 that was shown to inhibit growth factorinduced DNA synthesis without altering cell viability (Dudley et al., 1995). First, we examined the ability of PD 098059 to inhibit activation of ERK by extracellular ATP. Primary cultures of astrocytes were treated with PD $098059(50 \mu \mathrm{M})$ for $30 \mathrm{~min}$ before addition of ATP (100 $\mu \mathrm{M}, 5 \mathrm{~min})$, cellular lysates were subjected to SDS-PAGE, and phosphorylated ERK1 and ERK2 were detected by immunoblot analysis. As shown in Figure $7 A$, PD 098059 greatly reduced extracellular ATP-evoked phosphorylation of ERK1 and ERK2. ERK activity assays confirmed this

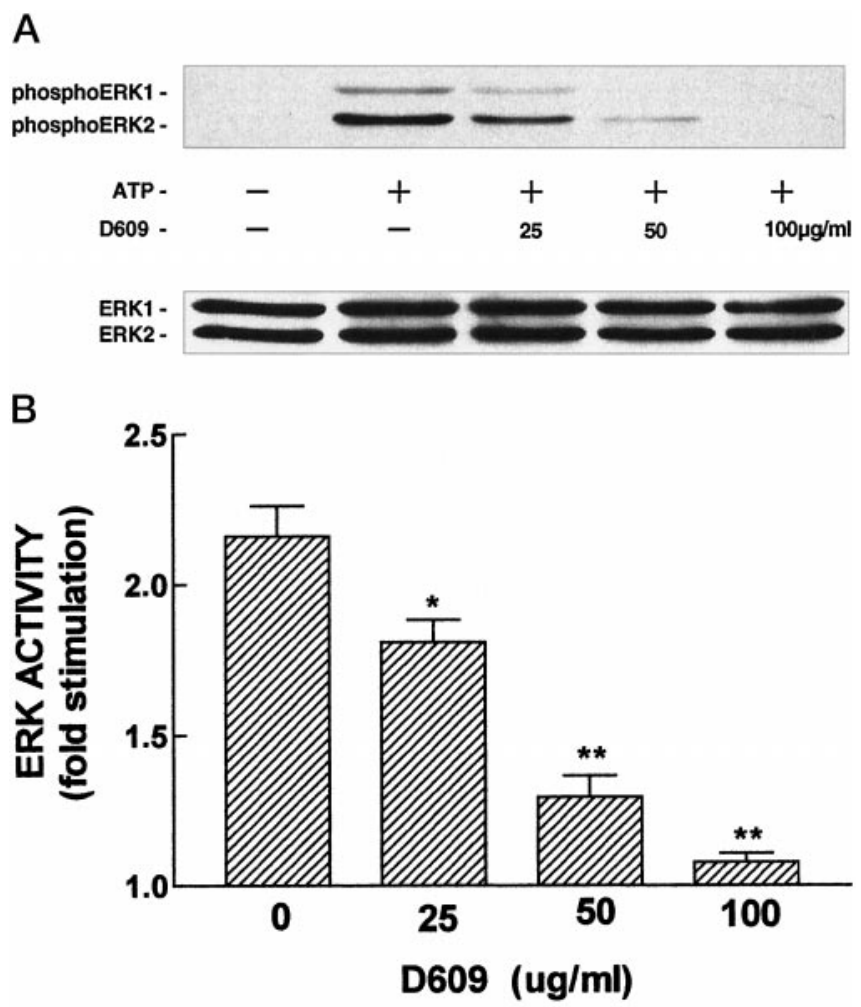

Figure 6. Inhibition of PC hydrolysis decreases the ability of ATP to stimulate ERK activity. Primary rat astrocytes were treated without or with the indicated concentrations of D609 for $60 \mathrm{~min}$ before addition of ATP $(100 \mu \mathrm{M})$ for $5 \mathrm{~min}$. In $A$, phosphorylated ERK1/ERK2 (top panel) and ERK1/ERK2 (bottom panel) were detected by immunoblotting as described in Materials and Methods. In $B$, ERK activity data (mean \pm SEM) were obtained from three independent experiments, each representing different seedings and conducted with duplicate culture plates. " 0 " indicates cultures treated with ATP only. ERK activity in untreated cultures was $43.3 \pm 4.9$ pmol phosphate transferred per minute per milligram of protein. ${ }^{*} p<0.001 ;{ }^{*} p<0.05$ for comparisons of ATP versus D609 + ATP.

finding (data not shown). We then investigated the ability of PD 098059 to inhibit ATP-induced mitogenic signaling. Primary cultures of astrocytes were treated with PD $098059(50 \mu \mathrm{M})$ for 30 min before the addition of ATP $(100 \mu \mathrm{M})$, and its effect on ATP-induced DNA synthesis was measured. As shown in Figure $7 B$, PD 098059 blocked the ability of ATP to stimulate DNA synthesis. Additional experiments demonstrated that $50 \mu \mathrm{M} P D$ 098059 did not affect cellular viability as assessed by measuring protein synthesis ( ${ }^{3} \mathrm{H}$-leucine incorporation; data not shown). These results demonstrate that the ERK/MAPK cascade mediates mitogenic signaling by $\mathrm{P} 2 \mathrm{Y}$ receptors.

\section{DISCUSSION}

The main findings of the studies presented here are that (1) signaling from $\mathrm{P} 2 \mathrm{Y}$ receptors to ERK is independent of the PI-PLC/calcium pathway and involves a calcium-independent PKC isoform as well as PC hydrolysis, which may be catalyzed by PLD, and (2) the ERK/MAPK cascade mediates mitogenic signaling by $\mathrm{P} 2 \mathrm{Y}$ receptors.

\section{Components of the signaling pathway from P2Y purinergic receptors to the ERK/MAPK cascade in primary cultures of rat cortical astrocytes}

The role of PKC in GPCR/ERK signaling pathways has not been completely defined. In some cases, GPCRs can be coupled to 
A
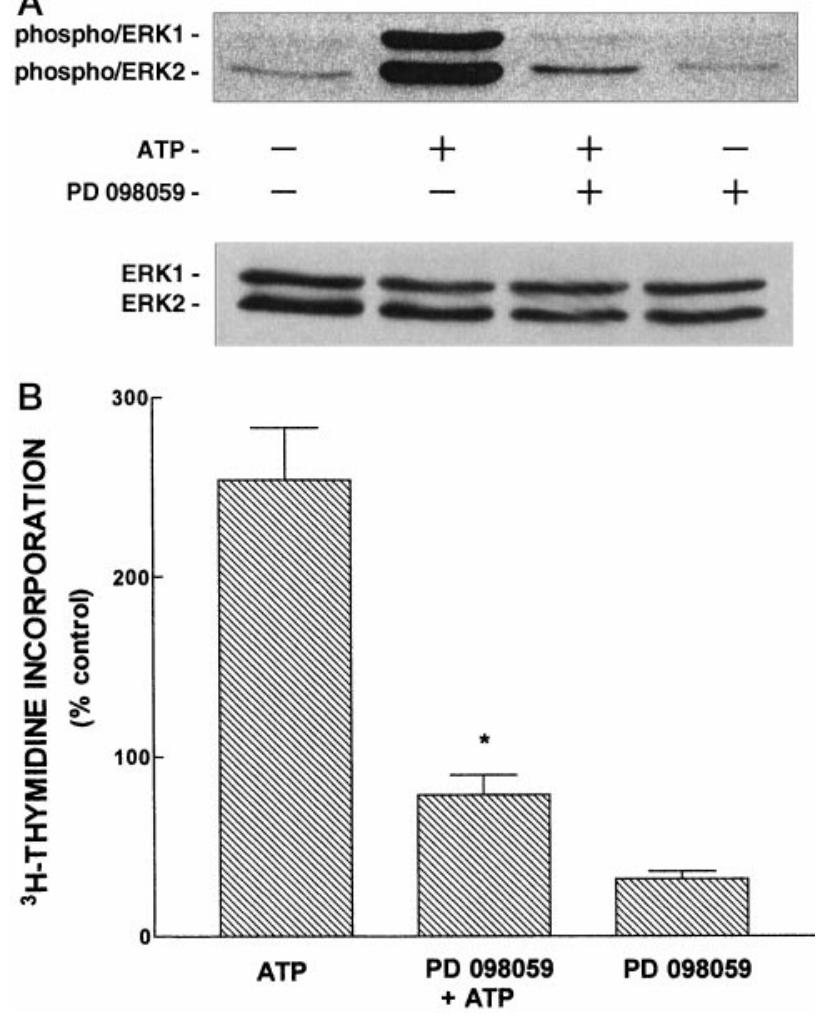

Figure 7. Extracellular ATP-evoked mitogenic signaling is mediated by the ERK/MAPK cascade. In $A$, primary rat astrocyte cultures were treated with ATP $(100 \mu \mathrm{M}, 5 \mathrm{~min})$, or with PD $098059(50 \mu \mathrm{M})$ for $30 \mathrm{~min}$ before addition of ATP $(100 \mu \mathrm{M}, 5 \mathrm{~min})$, cells were lysed, and lysates containing equivalent amounts of protein were subjected to SDS-PAGE. Immunoblots were probed with antibodies that recognize phosphorylated ERK1/ERK2 (top panel) or ERK1/ERK2 (bottom panel). In B, primary rat astrocyte cultures were treated with ATP $(100 \mu \mathrm{M})$, or with PD 098059 $(50 \mu \mathrm{M})$ for $30 \mathrm{~min}$ before addition of ATP, and DNA synthesis was determined as described in Materials and Methods. Values are given as the mean $\pm \mathrm{SE}$ of the mean and were obtained from three independent experiments, each conducted in quadruplicate and with different seedings. ${ }^{3} \mathrm{H}$-thymidine incorporation in untreated cultures was $1055 \pm 358 \mathrm{cpm}$ per culture well. ${ }^{*} p<0.001$ for comparison of ATP versus PD $098059+$ ATP.

ERK by both PKC-dependent and -independent pathways, thereby suggesting multiple signaling pathways from a specific receptor to ERK. For example, signaling from endothelin-1 receptors to ERK was reduced $\sim 50 \%$ by chronic phorbol ester treatment in mesangial cells (Wang et al., 1992), cardiac myocytes (Bogoyevitch et al., 1994), and astrocytes (Cazaubon et al., 1993). The studies presented here indicate that $\mathrm{PKC}$ is a crucial element of the pathway linking P2Y receptors to the ERK/MAPK cascade in primary cultures of cortical astrocytes because inhibition or downregulation of PKC reduced the ability of extracellular ATP to stimulate ERK activity by $\sim 90 \%$. To our knowledge, these studies are the first to document in brain cells that PKC is upstream of ERK in this P2Y receptor signaling pathway.

It is well established that $\mathrm{P} 2 \mathrm{Y}$ receptors in astrocytes are also coupled to PI-PLC (Pearce et al., 1989; Neary et al., 1991; Kastritsis et al., 1992; Salter and Hicks, 1994, 1995; King et al., 1996; Centemeri et al., 1997). Because signaling from P2Y receptors to ERK is dependent on PKC, this raised the possibility that P2Y receptors signal to ERK via PI-PLC. However, evidence presented here indicates that this is not the case. Inhibition of PI-PLC blocked the ability of extracellular ATP to stimulate formation of inositol phosphates but did not significantly reduce activation of ERK, thereby indicating that $\mathrm{P} 2 \mathrm{Y}$ receptors are coupled independently to PI-PLC and ERK. Moreover, chelation of intracellular or extracellular calcium did not decrease the ability of extracellular ATP to activate ERK, thereby suggesting that calcium-dependent protein kinases such as Pyk2 (Lev et al., 1995) or calcium-dependent isoforms of PKC are not upstream of ERK. Consistent with this was the finding that Gö 6976, which preferentially inhibits calcium-dependent PKC isoforms (Martiny-Baron et al., 1993), was significantly less effective in reducing the ability of extracellular ATP to activate ERK than GF10290X, an inhibitor of both calcium-dependent and -independent PKC isoforms. A previous study using the PKC inhibitor CGP 41251, which displays selectivity for calciumdependent PKC isoforms, implicated the involvement of a calcium-independent PKC isoform in signaling from P2Y receptors to ERK in renal mesangial cells, but this report did not examine PKC translocation induced by ATP (Huwiler and Pfeilschifter, 1994). Here we have found that a calciumindependent isoform, $\mathrm{PKC} \delta$, was rapidly translocated from the cytosol to the membrane on stimulation of P2Y receptors, and this translocation occurred before ERK activation. Although studies with antisense oligonucleotides or dominant negative mutants are needed to further establish the role of $\mathrm{PKC} \delta$, our findings in primary cells are in agreement with a recent report using COS cells in which overexpression of a constitutively active mutant of PKC $\delta$ was sufficient to activate MEK and ERK (Ueda et al., 1996). Overexpression of another calcium-dependent isoform, PKC $\epsilon$, or a calcium-dependent isoform, $\mathrm{PKC} \alpha$, did not activate MEK or ERK. In addition, PKC 8 -evoked activation of MEK and ERK was not blocked by overexpression of an inactive mutant of Ras, thereby indicating that $\mathrm{PKC} \delta$ can activate the ERK/MAPK cascade in a manner independent of Ras. Previous studies suggest that signaling from P2Y receptors to ERK in astrocytes does not involve Ras (Neary and Zhu, 1994; Neary, 1996).

Because a calcium-independent PKC isoform mediates signaling from P2Y receptors to the ERK/MAPK cascade in primary cultures of rat cortical astrocytes, we investigated the possibility that $\mathrm{P} 2 \mathrm{Y}$ receptors are coupled to ERK by phospholipases that are not directly linked to calcium signaling and yet can generate diacylglycerol for PKC activation. PC-PLC and PLD are two such enzymes that have been implicated in mitogenesis (Cai et al., 1993; Boarder, 1994). Hydrolysis of PC by PC-PLC yields diacylglycerol, which can then activate PKC isoforms. Alternatively, PC hydrolysis by PLD generates choline and phosphatidic acid; the latter can be converted to diacylglycerol by phosphatidic acid phosphohydrolase. Because ATP stimulated a rapid formation of choline rather than phosphocholine, PLD rather than PC-PLC may catalyze PC hydrolysis after occupancy of P2Y receptors. Previous studies have reported that $\mathrm{P} 2 \mathrm{Y}$ receptors are linked to PLD in astrocytes (Gustavsson et al., 1993) as well as endothelial cells (Martin and Michaelis, 1989; Pirotton et al., 1990; Purkiss and Boarder, 1992), promyelocytic leukemia cells (Xie et al., 1991), renal mesangial cells (Pfeilschifter and Merriweather, 1993), and canine kidney cells (Balboa et al., 1994). However, no information is available on the role of PLD-catalyzed PC hydrolysis in coupling P2Y receptors to the ERK/MAPK cascade.

To determine the involvement of PC hydrolysis in signaling from P2Y receptors to ERK, we used an inhibitor of PC hydrolysis and diacylglycerol production, D609 (Muller-Decker, 1989; Schutze et al., 1992; Cai et al., 1993; Inui et al., 1994; Kiss and 
Tomono, 1995; van Dijk et al., 1997). Studies with this inhibitor have shown that PC hydrolysis is upstream of the ERK/MAPK cascade in some signaling systems. For example, in NIH 3 T3 cells, D609 inhibited EGF-, TPA-, and serum-evoked phosphorylation of Raf (Cai et al., 1993). In Rat-1 fibroblasts, D609 inhibited PDGF-induced activation of ERK, but EGF-induced activation of ERK was unaffected by D609 (van Dijk et al., 1997). Expression of the G-protein-coupled 5-HT1A receptor in Chinese hamster ovary cells promoted activation of ERK2, and this activation was partially inhibited by D609 (Cowen et al., 1996). As reported here, we found that D609 inhibited extracellular ATP stimulation of ERK activity, thereby indicating for the first time that PC hydrolysis plays an important role in coupling $\mathrm{P} 2 \mathrm{Y}$ receptors to the ERK/MAPK cascade.

Inhibition of the ATP-evoked activation of ERK/MAPK by pertussis toxin suggests that the response is mediated at least in part by $G \alpha$ subunits such as $G_{i}$ or $G_{o}$, which are sensitive to pertussis toxin. By contrast, previous work has shown that pertussis toxin does not affect ATP-evoked mobilization of intracellular calcium in astrocytes from rat cerebral cortex (Bruner and Murphy, 1993a,b) and spinal cord (Ho et al., 1995; Salter and Hicks, 1995), thereby indicating that signaling from P2Y receptors to PI-PLC involves a G-protein insensitive to pertussis toxin, such as $G_{\mathrm{q}} / \mathrm{G}_{11}$ subclass, which lacks a site for ADP ribosylation. Our finding that the coupling of P2Y receptors to the ERK/ MAPK cascade is not dependent on PI-PLC is consistent with these results because if PI-PLC were involved in signaling from $\mathrm{P} 2 \mathrm{Y}$ receptors to ERK, pertussis toxin would not be expected to diminish the ability of ATP to activate ERK. Instead, we found that signaling from $\mathrm{P} 2 \mathrm{Y}$ receptors to ERK was reduced by 65$70 \%$, thereby suggesting the involvement of a pertussis toxinsensitive G-protein. Interestingly, pertussis toxin did not inhibit hypo-osmotic activation of ERK in astrocytes; in this case, ERK activation was dependent on calcium but independent of PKC (Schliess et al., 1996). Thus, hypo-osmotic signaling to the ERK/ MAPK cascade in astrocytes differs markedly from the P2Y/ERK pathway, because in the latter case our findings indicate that signaling is dependent on PKC, independent of calcium, and partially blocked by pertussis toxin. The pertussis toxin-sensitive protein involved in signaling from $\mathrm{P} 2 \mathrm{Y}$ receptors to the ERK/ MAPK cascade may be $G_{i}$ or $G_{o}$. On the basis of the findings of van Biesen et al. (1996a), we speculate that $G_{o}$ is more likely to be implicated because coupling of GPCRs to the ERK/MAPK cascade by $G_{i}$ involved a protein tyrosine kinase but not PKC, whereas coupling of GPCRs to the ERK/MAPK cascade via $P K C$ involved a $G_{o}$ protein.

As demonstrated here, signaling from $\mathrm{P} 2 \mathrm{Y}$ receptors to the ERK cascade in astrocytes is independent of the PI-PLC/calcium pathway. Activation of signaling pathways by GPCRs may depend on the type of G-protein that links receptors to specific effectors, e.g., P2Y receptors may be coupled to PI-PLC via $\mathrm{G}_{\mathrm{q}}$ and to ERK signaling via $G_{o}$ or $G_{i}$. Another possibility is that because four subtypes of $\mathrm{P} 2 \mathrm{Y}$ receptors, $\mathrm{P} 2 \mathrm{Y}_{1}, \mathrm{P} 2 \mathrm{Y}_{2}, \mathrm{P} 2 \mathrm{Y}_{4}$, and $\mathrm{P} 2 \mathrm{Y}_{6}$, have been cloned from rat tissues, ERK and PI-PLC pathways could be activated by separate subtypes. The P2Y receptor agonists ATP, UTP, and 2-methylthio-ATP (2-MeSATP) stimulate both calcium mobilization and ERK activation in rat cortical astrocytes (King et al., 1996). This suggests that receptor subtypes such as $\mathrm{P}_{2} \mathrm{Y}_{1}$ (2-MeSATP- and ATP-preferring), P2 $\mathrm{Y}_{2}$ and P2Y $\mathrm{Y}_{4}$ (ATP- and UTP-preferring), and $\mathrm{P}^{2} \mathrm{Y}_{6}$ (UTP-preferring) may be coupled to both pathways. However, further studies are needed to determine the array of $\mathrm{P} 2 \mathrm{Y}$ receptor subtypes expressed in astrocytes and their linkage to specific signaling pathways. Such efforts would be aided by the development of highly selective agonists and antagonists to distinguish between endogenous P2Y receptor subtypes.

\section{The ERK/MAPK cascade mediates mitogenic signaling by ATP/P2Y receptors in astrocytes}

Recent studies have demonstrated the importance of the ERK/ MAPK cascade in cellular proliferation and differentiation (for review, see Marshall, 1995; Seger and Krebs, 1995). Much of the evidence for the critical role of the ERK/MAPK cascade in cell growth has come from experiments in which active or inactive mutants of members of the cascade or upstream signaling elements have been overexpressed in transformed cells. This information can then be used as a basis to investigate the role of the ERK/MAPK cascade in mitogenic signaling from specific receptors in nontransformed, primary cultures as well as the components of the pathway that link the receptors to the cascade. Extracellular ATP acts as a mitogenic signal in primary cultures of cerebral cortical astrocytes from newborn rats (Neary et al., 1994a,b). Because ATP also stimulates ERK activity in these cells (Neary and Zhu, 1994; King et al., 1996), this suggests that ERK is involved in ATP-induced mitogenesis. However, in addition to phosphorylating and activating transcription factors involved in gene expression needed for proliferation and differentiation, ERK has other targets, including proteins in the cytoplasm, membrane, and cytoskeleton; therefore, ERK may have other roles besides regulating cell growth (Seger and Krebs, 1995). For example, by phosphorylating myosin light-chain kinase, ERK can regulate cell motility by a pathway independent of gene transcription (Klemke et al., 1997). Thus, the stimulation of ERK by extracellular ATP does not provide sufficient evidence to conclude that ERK mediates mitogenic signaling by ATP/P2Y receptors in astrocytes. To investigate this question, we used PD 098059, an inhibitor of the ERK activator MEK1 (Dudley et al., 1995). PD 098059 has been shown to block ERK stimulation and to inhibit growth factor-induced proliferation in Swiss 3T3 mouse fibroblasts and rat kidney cells at concentrations that were not cytotoxic. PD 098059 is highly selective for MEK1, as evidenced by its failure to inhibit 18 other serine/threonine protein kinases in vitro and in vivo, including the ERK homolog Jun N-terminal kinase (also known as stress-activated protein kinase) (Alessi et al., 1995). If the ATP-evoked activation of ERK and the ATPinduced mitogenic response are causally related, PD 098059 should block the ability of ATP to stimulate DNA synthesis. Indeed, this was observed (Fig. $7 B$ ), thereby indicating the importance of the ERK/MAPK cascade in mediating mitogenic signaling by ATP receptors in astrocytes.

\section{REFERENCES}

Abbracchio MP, Burnstock G (1994) Purinoceptors: are there families of P2X and P2Y purinoceptors? Pharmacol Ther 64:445-475.

Abbracchio MP, Saffrey MJ, Hopker V, Burnstock G (1994) Modulation of astroglial cell proliferation by analogues of adenosine and ATP in primary cultures of rat striatum. Neuroscience 59:67-76.

Abbracchio MP, Ceruti S, Langfelder R, Cattabeni F, Saffrey MJ, Burnstock G (1995) Effects of ATP analogues and basic fibroblast growth factor on astroglial cell differentiation in primary cultures of rat striatum. Int J Dev Neurosci 13:685-693.

Ahn NG, Weie JE, Chan CP, Krebs EG (1990) Identification of multiple epidermal growth factor-stimulated protein serine/threonine kinases from Swiss 3T3 cells. J Biol Chem 265:11487-11494.

Alessi DR, Cuenda A, Cohen P, Dudley DT, Saltiel AR (1995) PD 098059 is a specific inhibitor of the activation of mitogen-activated protein kinase kinase in vitro and in vivo. $\mathrm{J}$ Biol Chem 270:27489-27494. 
Avruch J, Zhang X-F, Kyriakis JM (1994) Raf meets Ras: completing the framework of a signal transduction pathway. Trends Biochem Sci 19:279-283.

Balboa MA, Firestein BL, Godson C, Bell KS, Insel PA (1994) Protein kinase $\mathrm{C} \alpha$ mediates phospholipase $\mathrm{D}$ activation by nucleotides and phorbol ester in Madin-Darby canine kidney cells. J Biol Chem 269:10511-10516.

Bender AS, Neary JT, Norenberg MD (1993) Role of phosphoinositide hydrolysis in astrocyte volume regulation. J Neurochem 61:1506-1514.

Bleasdale JE, Thaker R, Gremban RS, Bundy GL, Fitzpatrick FA, Smith RJ (1990) Selective inhibition of receptor-coupled phospholipase $\mathrm{C}$-dependent processes in human platelets and polymorphonuclear neurotrophils. J Pharmacol Exp Ther 255:756-768.

Boarder MR (1994) A role for phospholipase D in control of mitogenesis. Trends Pharmacol Sci 15:57-62.

Bogoyevitch MA, Glennon PE, Andersson MB, Clerk A, Lazou A, Marshall CJ, Parker PJ, Sugden PH (1994) Endothelin-1 and fibroblast growth factors stimulate the mitogen-activated protein kinase cascade in cardiac myocytes. J Biol Chem 269:1110-1119.

Bruner G, Murphy S (1993a) Purinergic P2Y receptors on astrocytes are directly coupled to phospholipase A2. Glia 7:219-224.

Bruner G, Murphy S (1993b) UTP activates multiple second messenger systems in cultured rat astrocytes. Neurosci Lett 162:105-108.

Burnstock G (1978) A basis for distinguishing two types of purinergic receptors. In: Cell and membrane receptors for drugs and hormones: a multidisciplinary approach (Bolis L, Straub RW, eds), pp 107-118. New York: Raven.

Cai H, Erhardt P, Troppmair J, Diaz-Meco MT, Sithanandam G, Rapp UR, Moscat J, Cooper GM (1993) Hydrolysis of phosphatidylcholine couples Ras to activation of Raf protein kinase during mitogenic signal transduction. Mol Cell Biol 13:7645-7651.

Cazaubon S, Parker PJ, Strosberg AD, Couraud P-O (1993) Endothelins stimulate tyrosine phosphorylation and activity of p42/mitogenactivated protein kinase in astrocytes. Biochem J 293:381-386.

Centemeri C, Bolego C, Abbracchio MP, Cattabeni F, Puglisi L, Burnstock G, Nicosia S (1997) Characterization of the $\mathrm{Ca}^{2+}$ responses evoked by ATP and other nucleotides in mammalian brain astrocytes. Br J Pharmacol 121:1700-1706.

Cowen DS, Sowers RS, Manning DR (1996) Activation of a mitogenactivated protein kinase (ERK2) by the 5-hydroxytryptamine $1 \mathrm{~A}$ receptor is sensitive not only to inhibitors of phosphatidylinositol 3-kinase but to an inhibitor of phosphatidylcholine hydrolysis. J Biol Chem 271:22297-22300.

Dudley DT, Pang L, Decker SJ, Bridges AJ, Saltiel AR (1995) A synthetic inhibitor of the mitogen-activated protein kinase cascade. Proc Natl Acad Sci USA 92:7686-7689.

Edwards FA, Gibb AJ, Colquhoun D (1992) ATP receptor-mediated synaptic currents in the central nervous system. Nature 359:144-147.

Eng LF (1988) Regulation of glial intermediate filaments in astrogliosis. In: The biochemical pathology of astrocytes (Norenberg MD, Hertz L, Schousboe A, eds), pp 79-90. New York: Alan R. Liss.

Gott AL, Mallon BS, Paton A, Groome N, Rumsby MG (1994) Rat brain glial cells in primary culture and subculture contain the delta, epsilon, and zeta subspecies of protein kinase $\mathrm{C}$ as well as the conventional subspecies. Neurosci Lett 171:117-120.

Gustavsson L, Lundqvist C, Hansson E (1993) Receptor-mediated phospholipase D activity in primary astroglial cultures. Glia 8:249-255.

Harms L, Finta EP, Tschopl M, Illes P (1992) Depolarization of rat locus coeruleus neurons by adenosine $5^{\prime}$-triphosphate. Neuroscience 48:941-952.

Ho C, Hicks J, Salter MW (1995) A novel P2-purinoceptor expressed by a subpopulation of astrocytes from the dorsal spinal cord of the rat. $\mathrm{Br} \mathbf{J}$ Pharmacol 116:2909-2918.

Huwiler A, Pfeilschifter J (1994) Stimulation by extracellular ATP and UTP of the mitogen-activated protein kinase cascade and proliferation of rat renal mesangial cells. Br J Pharmacol 113:1455-1463.

Inui H, Kitami Y, Tani M, Kondo T, Inagami T (1994) Differences in signal transduction between platelet-derived growth factor (PDGF) $\alpha$ and $\beta$ receptors in vascular smooth muscle cells: PDGF-BB is a potent mitogen, but PDGF-AA promotes only protein synthesis without activation of DNA synthesis. J Biol Chem 269:30546-30552.

Karin M (1995) The regulation of AP-1 activity by mitogen-activated protein kinases. J Biol Chem 270:16483-16486.

Kastritsis CH, Salm AK, McCarthy K (1992) Stimulation of the P2y purinergic receptor on type 1 astroglia results in inositol phosphate formation and calcium mobilization. J Neurochem 58:1277-1284.

King BF, Neary JT, Zhu Q, Wang S, Norenberg MD, Burnstock G (1996) P2 purinoceptors in rat cortical astrocytes: expression, calciumimaging and signalling studies. Neuroscience 74:1187-1196.

Kiss Z, Tomono M (1995) Compound D609 inhibits phorbol esterstimulated phospholipase D activity and phospholipase C-mediated phosphatidylethanolamine hydrolysis. Biochim Biophys Acta 1259:105-108.

Klemke RL, Cai S, Giannini AL, Gallagher PJ, de Lanerolle P, Cheresh DA (1997) Regulation of cell motility by mitogen-activated protein kinase. J Cell Biol 137:481-492.

Laemmli UK (1970) Cleavage of structural proteins during the assembly of the head of bacteriophage T4. Nature 227:680-685.

Lev S, Moreno H, Martinez R, Canoll P, Peles E, Musacchio JM, Plowman GD, Rudy B, Schlessinger J (1995) Protein tyrosine kinase PYK2 involved in $\mathrm{Ca}^{2+}$-induced regulation of ion channel and MAP kinase functions. Nature 376:737-745.

Marshall CJ (1995) Specificity of receptor tyrosine kinase signaling: transient versus sustained extracellular signal-regulated kinase activation. Cell 80:179-185.

Martin TW, Michaelis K (1989) P2-purinergic agonists stimulate phosphodiesteratic cleavage of phosphatidylcholine in endothelial cells. Evidence for activation of phospholipase D. J Biol Chem 264:8847-8856.

Martiny-Baron G, Kazanietz MG, Mischak H, Blumberg PM, Kochs G, Hug H, Marme D, Schachtele C (1993) Selective inhibition of protein kinase C isozymes by the indolocarbazole Go 6976. J Biol Chem 268:9194-9197.

Muller-Decker K (1989) Interruption of TPA-induced signals by an antiviral and antitumoral xanthate compound: inhibition of a phospholipase C-type reaction. Biochem Biophys Res Commun 162:198-205.

Neary JT (1996) Trophic actions of extracellular ATP on astrocytes, synergistic interactions with fibroblast growth factors, and underlying signal transduction mechanisms. Ciba Found Symp 198:130-141.

Neary JT (1997) MAPK cascades in cell growth and death. News Physiol Sci 12:286-293.

Neary JT, Zhu Q (1994) Signaling by ATP receptors in astrocytes. NeuroReport 5:1617-1620.

Neary JT, Norenberg LOB, Norenberg MD (1988) Protein kinase C in primary astrocyte cultures: cytoplasmic localization and translocation by a phorbol ester. J Neurochem 50:1179-1184.

Neary JT, Laskey R, van Breemen C, Blicharska J, Norenberg LOB, Norenberg MD (1991) ATP-evoked calcium signal stimulates protein phosphorylation/dephosphorylation in astrocytes. Brain Res 566:89-94.

Neary JT, Whittemore SR, Zhu Q, Norenberg MD (1994a) Synergistic activation of DNA synthesis in astrocytes by fibroblast growth factor and extracellular ATP. J Neurochem 63:490-494.

Neary JT, Baker L, Jorgensen SL, Norenberg MD (1994b) Extracellular ATP induces stellation and increases GFAP content and DNA synthesis in primary astrocyte cultures. Acta Neuropathol 87:8-13.

Neary JT, Rathbone MP, Cattabeni F, Abbracchio MP, Burnstock G (1996) Trophic actions of extracellular nucleotides and nucleosides on glial and neuronal cells. Trends Neurosci 19:13-18.

Pearce B, Murphy S, Jeremy J, Morrow C, Dandona P (1989) ATPevoked $\mathrm{Ca}^{2+}$ mobilization and prostanoid release from astrocytes: P2-purinergic receptors linked to phosphoinositide hydrolysis. J Neurochem 52:971-977.

Peterson GL (1983) Determination of total protein. Methods Enzymol 91:95-119.

Pfeilschifter J, Merriweather C (1993) Extracellular ATP and UTP activation of phospholipase $\mathrm{D}$ is mediated by protein kinase $\mathrm{C}-\epsilon$ in rat renal mesangial cells. Br J Pharmacol 110:847-853.

Pirotton S, Robaye B, Lagneau C, Boeynaems J-M (1990) Adenine nucleotides modulate phosphatidylcholine metabolism in aortic endothelial cells. J Cell Physiol 142:449-457.

Purkiss JR, Boarder MR (1992) Stimulation of phosphatidate synthesis in endothelial cells in response to P2-receptor activation. Biochem J 287:31-36.

Rathbone MP, Middlemiss PJ, Kim J-L, Gysbers JW, DeForge SP, Smith RW, Hughes DW (1992) Adenosine and its nucleotides stimulate proliferation of chick astrocytes and human astrocytoma cells. Neurosci Res 13:1-17.

Salter MW, Hicks JL (1994) ATP-evoked increases in intracellular cal- 
cium in neurons and glia from the dorsal spinal cord. J Neurosci 14:1563-1575.

Salter MW, Hicks JL (1995) ATP causes release of intracellular $\mathrm{Ca}^{2+}$ via the phospholipase $C \beta /$ IP3 pathway in astrocytes from the dorsal spinal cord. J Neurosci 15:2961-2967.

Schliess F, Sinning R, Fischer R, Schmalenbach C, Haussinger D (1996) Calcium-dependent activation of Erk-1 and Erk-2 after hypo-osmotic astrocyte swelling. Biochem J 320:167-171.

Schutze S, Potthoff K, Machleidt T, Berkovic D, Wiegmann K, Kronke M (1992) TNF activates NF-kB by phosphatidylcholine-specific phospholipase C-induced "acidic" sphingomyelin breakdown. Cell 71:765-776.

Seger R, Krebs EG (1995) The MAPK signaling cascade. FASEB J 9:726-735.

Sevetson BR, Kong X, Lawrence Jr JC (1993) Increasing cAMP attenuates activation of mitogen-activated protein kinase. Proc Natl Acad Sci USA 90:10305-10309.

Shen KZ, North RA (1993) Excitation of rat locus coeruleus neurons by adenosine $5^{\prime}$-triphosphate: ionic mechanism and receptor characterization. J Neurosci 13:894-899.

Ueda Y, Hirai S, Osada S, Suzuki A (1996) Protein Kinase C $\delta$ activates the MEK-ERK pathway in a manner independent of Ras and dependent on Raf. J Biol Chem 271:23512-23519.

van Biesen T, Hawes BE, Raymond JR, Luttrell LM, Koch WJ, Lefkow- itz RJ (1996a) Go-protein alpha-subunits activate mitogen-activated protein kinase via a novel protein kinase $\mathrm{C}$-dependent mechanism. J Biol Chem 271:1266-1269.

van Biesen T, Luttrell LM, Hawes BE, Lefkowitz RJ (1996b) Mitogenic signaling via $\mathrm{G}$ protein-coupled receptors. Endocr Rev 17:698-714.

van Dijk MCM, Muriana FJG, de Widt J, Hilkmann H, van Blitterswijk WJ (1997) Involvement of phosphatidylcholine-specific phospholipase $\mathrm{C}$ in platelet-derived growth factor-induced activation of the mitogenactivated protein kinase pathway in rat-1 fibroblasts. J Biol Chem 272:11011-11016.

Vance DE, Trip E, Paddon HB (1980) Poliovirus increases phosphatidylcholine biosynthesis in HeLa cells by stimulation of the rate-limiting reaction catalyzed by CTP:phosphocholine cytidylytransferase. J Biol Chem 255:1064-1069.

Wang Y, Simonson MS, Pouyssegur J, Dunn MJ (1992) Endothelin rapidly stimulates mitogen-activated protein kinase activity in rat mesangial cells. Biochem J 287:589-594.

Xie M, Jacobs LS, Dubyak GR (1991) Regulation of phospholipase D and primary granule secretion by P2-purinergic- and chemotactic peptide-receptor agonists is induced during granulocytic differentiation of HL-60 cells. J Clin Invest 88:45-54.

Yahame HK, Fung BKK (1993) Covalent modifications of G proteins. Annu Rev Pharmacol Toxicol 33:201-241. 